\title{
Soil Respiration and Carbon Balance Under Cover Crop in a no-Till Tropical Fruit Orchard
}

\author{
Ariel Freidenreich ${ }^{1}$, Sanku Dattamudi ${ }^{1}$, Yuncong C. $L i^{2}$ and Krishnaswamy Jayachandran ${ }^{1 *}$ \\ ${ }^{1}$ Department of Earth and Environment, Florida International University, Miami, FL, United States, ${ }^{2}$ Soil and Water Sciences \\ Department, Tropical Research and Education Center, IFAS, University of Florida, Homestead, FL, United States
}

OPEN ACCESS

Edited by:

Rahul Mahadev Shelake, Gyeongsang National University,

South Korea

Reviewed by:

Pankaj Prakash Verma, Central Potato Research Institute (ICAR), India

Rajesh Ramdas Waghunde, Navsari Agricultural University, India

*Correspondence:

Krishnaswamy Jayachandran jayachan@fiu.edu

Specialty section

This article was submitted to Soil Processes,

a section of the journal

Frontiers in Environmental Science

Received: 29 August 2021 Accepted: 01 December 2021 Published: 23 December 2021

Citation:

Freidenreich A, Dattamudi S, Li YC and

Jayachandran K (2021) Soil

Respiration and Carbon Balance Under Cover Crop in a no-Till Tropical

Fruit Orchard.

Front. Environ. Sci. 9:766638.

doi: 10.3389/fenvs.2021.766638
Agricultural practices, specifically crop and land management schemes, greatly influence the ability of soil to produce $\mathrm{CO}_{2}$ under varying conditions. A 2-year research study was planned to quantify carbon-dioxide $\left(\mathrm{CO}_{2}\right)$ emission fluxes and total C (TC) contribution in a no-till tropical soil under carambola with sunn hemp-velvet bean cover cropping (CC) systems. Composted poultry manure (PM) was applied as an additional $\mathrm{N}$ source. The treatments were fallow control $(F)$, fallow with PM $(F M)$, sunn hemp $(\mathrm{SH})$, SH with PM $(\mathrm{SHM})$, velvet bean (VB), and $\mathrm{VB}$ with $\mathrm{PM}(\mathrm{VBM})$. Average daily $\mathrm{CO}_{2}$ emission from $\mathrm{VB}$ was 23 and 15\% higher than control and SH plots, respectively, during CC growing season. Similarly, $\mathrm{CO}_{2}$ emission after $\mathrm{CC}$ termination was highest from VB plots. About $17 \%$ higher $\mathrm{CO}_{2}-\mathrm{C}$ emission was observed from manure applied plots which indicates that additional food sources stimulated microbial activity in the soils and subsequently produced more $\mathrm{CO}_{2}$. However, total $\mathrm{C}$ contribution in $\mathrm{SH}$ plots were significantly higher than in VB plots and was more apparent when manure was not applied. Soil and air temperature played key roles in $\mathrm{CO}_{2}$ emission, specifically during the $\mathrm{CC}$ growing season. Considering both input and output parameters of $\mathrm{C}$ in the soil, our results suggest that $\mathrm{SH}$ has the better potential in reducing $\mathrm{CO}_{2}$ emission and accumulating more $\mathrm{C}$ in the soil than VB in tropical fruit orchard.

Keywords: cover crop, Sunn hemp (Crotalaria juncea), Velvet bean (Mucuna pruriens), Carambola (Averrhoa carambola), soil health, soil respiration, carbon balance

\section{INTRODUCTION}

Soil respiration plays a major role in global carbon (C) cycle (Schlesinger and Andrews, 2000; Gougoulias et al., 2014) and is actively related to soil ecosystem productivity. Studies identify conservation or sustainable agriculture as an effective option for enhancing $\mathrm{C}$ storage, and in some cases, minimizing $\mathrm{CO}_{2}$ loss from agricultural soil (Martínez-Mena et al., 2021; Jia et al., 2021). Typically, conservation or sustainable agriculture is the culmination of strategies for cultivating crops with minimal inputs, soil disturbances, and implementation of continuous soil cover (mulch) (Hobbs et al., 2008; Zhang and Peng, 2021). Cover cropping is recognized as one of the sustainable agricultural practices that influences soil $\mathrm{C}$ balance depending on soil types, land management, and environmental conditions. Ecosystem services provided from cover cropping include organic matter addition, soil structure improvement, weed control, nutrient management, and pollinator attraction, which are especially important in organic, low input systems (Scholberg et al., 2010). Sunn hemp (Crotalaria juncea L.) (SH) and velvet bean (Mucuna pruriens L. DC.) (VB) are leguminous cover 
crops (CC) with potential to contribute 4 to $14 \mathrm{Mg} \mathrm{ha}^{-1}$ soil organic C (SOC) in tropical climates (Wang et al., 2012; Rosolem et al., 2016).

When CCs are incorporated into a no-till farming system, they have the ability to enhance soil biodiversity and fertility through increasing soil $\mathrm{CN}$ fractions and improving aggregate stability (Rigon et al., 2020). While the addition of CCs can be beneficial for soil fertility and crop production, enhanced microbial activity in CC systems can also increase $\mathrm{CO}_{2}$ emission from soil (SanzCobena et al., 2014). In fact, $\mathrm{CO}_{2}$ emissions can even be heightened with the use of legume $\mathrm{CCs}$ due to the low C:N ratio of plant tissue produced (Alluvione et al., 2010; Muhammad et al., 2019). Therefore, a soil C balance is needed to elucidate both positive and negative aspects of these CCs in a fruit production setting. This research was conducted in an organically produced carambola (commonly known as starfruit (Averrhoa carambola)) orchard, which are commercially grown only in Florida within the mainland United States.

Traditionally, poultry manure (PM) is commonly applied as fertilizer in organic tropical fruit production systems (Canali et al., 2004; Jones et al., 2020). As over 10 billion kg of poultry litter is produced annually in the United States, composting poultry litter is a useful way to repurpose problematic waste into a nutrient source for crop production (Reddy et al., 2007). Repurposing the waste for agricultural purposes is a sustainable method of adding carbon (C) and nitrogen (N) to soils (Nyakatawa et al., 2001; Reddy et al., 2004), while reducing the risk of $\mathrm{N}$ leachate polluting natural systems (Kaiser et al., 2009). Because carambola requires intensive nutrient management during production (both at young and mature stages; Crane, 2016), growing of CCs combined with PM additions could be beneficial to soil health and quality, along with providing economic benefits to the farmers, making this a potentially ideal management strategy for tropical fruit producers.

We selected SH and VB as our study CCs because of their large biomass producing nature (average $14-21 \mathrm{Mg} \mathrm{ha}^{-1}$ ). These CCs have also proven to accumulate large amounts of SOC and to enhance soil health in South Florida (Wang et al., 2015). However, a comparative analysis of $\mathrm{C}$ budget from these 2 CCs has not been studied, specifically, in organic cultivation where SOM is expected to play a major role in the $\mathrm{C}$ balance. We also recognized that no literature is available on analyzing the effect of CCs on soil respiration under organic no-till carambola production in the US. Carambola contributes $\$ 3.7$ million per year to Florida's economy with much room for growth (Ballen et al., 2020) with an increasing popularity for the growers since organic avocado (major fruit crop in South Florida) production has been facing serious pest and pathogen problems throughout the last 10-12 years (Menocal et al., 2018). Adding CCs can apply to many tropical fruit grove settings and results from this research may lay the foundation for this practice to be utilized throughout South Florida. Therefore, the specific objectives of this study were to: a) evaluate the emissions of $\mathrm{CO}_{2}$ from $\mathrm{SH}$ and $\mathrm{VB}$ plots (with and without manure treatments) and $\mathrm{b}$ ) develop $\mathrm{C}$ budgets for both $\mathrm{CC}$ plots and elucidate the ability of $\mathrm{SH}$ and $\mathrm{VB}$ to mitigate $\mathrm{CO}_{2}$ emissions.

\section{MATERIALS AND METHODS}

\section{Site Characteristics and Treatments}

A two-season (2018 and 2019) field experiment was conducted in a multi-use certified organic fruit orchard (6.07 ha) located in the Redland Agricultural Area of South Florida, United States. Soil used for this experiment was a sandy loam (73\% sand, $17 \%$ clay, and $10 \%$ slit). At the start of the experiment, the soil had an average $\mathrm{pH}$ of 7.6 with $17 \%$ SOM content. Soil total carbon and nitrogen were 175 and $8.9 \mathrm{~g} \mathrm{~kg}^{-1}$, respectively, with soil electrical conductivity at $0.820 \mathrm{dS} / \mathrm{m}$. The soil in the RAA is categorized by the United States Department of Agriculture, National Resource Conservation Service (USDA, NRCS) as Krome Series soil. Prior to carambola being planted, mature sapodilla trees were grown in this area and treated with $5 \mathrm{~N}-3 \mathrm{P}-2 \mathrm{~K}$ USDA certified organic composted poultry manure. Average air and soil temperatures were $26.4^{\circ} \mathrm{C}$ and $28.8^{\circ} \mathrm{C}$, respectively, for summer and $21.4^{\circ} \mathrm{C}$ and $23.7^{\circ} \mathrm{C}$, respectively, for winter months. Relative humidity (\%) ranged from 81 to $86 \%$; average $\sim 83 \%$ per month and average monthly rainfall ranged from 11 to $35 \mathrm{~cm}$ during the wet season and 3-12 cm within the dry season.

Sunn hemp (cv: Tropic Sun) and velvet bean (var: pruriens) seeds were sowed via hand broadcast in a 3-year old carambola (cv: Hawaiian Super Sweet) orchard at seeding rates of $101 \mathrm{~kg} \mathrm{ha}^{-1}$ and $75.8 \mathrm{~kg} \mathrm{ha}^{-1}$, respectively. Sixty carambola trees were planted in two $122 \mathrm{~m}$ long rows (30 trees per row) with $7 \mathrm{~m}$ distance between rows and $3.8 \mathrm{~m}$ distance between each tree. The cover crop treatments were seeded directly in a circular fashion starting at the dripline (approx. $0.5 \mathrm{~m}$ radius from the trunk) and circling around the tree in a $1.25 \mathrm{~m}$ radius resulting in a planting area of $8.8 \mathrm{~m}^{2}$. Cover crop seeds were treated with OMRI certified seed inoculant (Verdesian Life Sciences, Cary, NC) to ensure robust plants with sufficient root nodulation. Both $\mathrm{CC}$ types were terminated 90 days after germination (DAG) but before flowering, followed by composted poultry manure $(5 \mathrm{~N}$ $3 \mathrm{P}-2 \mathrm{~K}$ USDA certified organic) application at $105 \mathrm{~kg} \mathrm{ha}^{-1}$ for both crops. Fallow (control), SH, and VB plots that received manure are noted as FM, SHM, and VBM in this manuscript. No manure was applied during CC growing seasons. Treatments were assigned in a completely randomized design (CRD) with nine replications for each treatment. We selected CRD as the experimental design based on 3-year old carambola seedlings that were within the same growth stage with very similar sizes and transplanted at the same time. With our small experimental area (0.2 ha), soils in the area are in relative homogeneity (based on previous studies conducted at this site). Biomass of $\mathrm{SH}$ and $\mathrm{VB}$ crops were measured by oven drying the biomass at $70^{\circ} \mathrm{C}$ for $72 \mathrm{~h}$. A timescale of cultural operations and sampling events are presented in Table 1.

\section{Sample Collection and Analysis}

Soil collars were installed (thin-walled polyvinyl chloride) after initial weeding at each tree (Figure 1) for in situ soil respiration measurements via LI-6400 XT Portable Photosynthesis Meter (Lincoln, Nebraska) with Soil $\mathrm{CO}_{2}$ Flux Chamber attachment (Figure 1C). Soil collars were $10 \mathrm{~cm}$ in diameter and $9 \mathrm{~cm}$ long, inserted $8 \mathrm{~cm}$ into the soil, excluding the litter layer, therefore 
TABLE 1 | Timeline for agricultural practices followed throughout the experiment.

\begin{tabular}{|c|c|c|c|c|c|c|c|c|c|c|c|c|}
\hline Practice & May & June & July & Aug & Sept & Oct & Nov & Dec & Jan & Feb & Mar & Apr \\
\hline 1.Cover crop germination & + & - & - & - & - & - & - & - & - & - & - & - \\
\hline 2. Cover crop growing period & + & + & + & - & - & - & - & - & - & - & - & - \\
\hline 3. Cover crop termination & - & - & - & + & - & - & - & - & - & - & - & - \\
\hline 4. Carbon dioxide emission sampling & + & + & + & + & + & + & + & + & + & + & + & + \\
\hline 5. Soil sample collection (before manure application) & - & - & - & + & + & + & + & + & - & + & - & + \\
\hline 6. Manure application & - & - & - & + & - & + & + & - & + & - & + & - \\
\hline
\end{tabular}

Note: "+" indicates months when practices occurred.

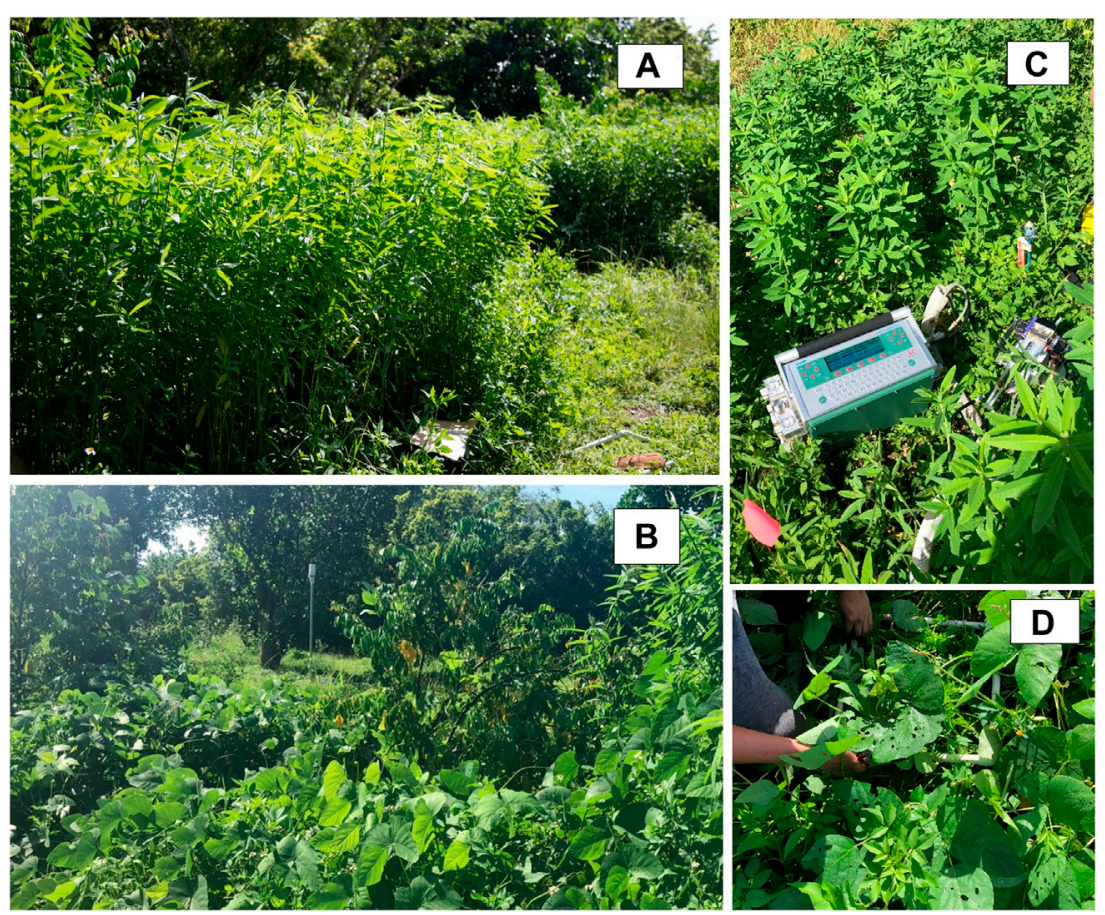

FIGURE 1 | Photographic images of (A) established sunn hemp (Crotalaria juncea) crop, (B) established velvet bean (Mucuna pruriens) crop around carambola, (C) in-situ soil $\mathrm{CO}_{2}$ efflux measurement from SH field, and (D) biomass harvesting of velvet bean.

emission of $\mathrm{CO}_{2}$ from soil is the direct indication of root and microbial respiration of that soil. Gas samples $\left(\mathrm{CO}_{2}\right)$ were collected every 2 weeks throughout the cover crop growing season (90 days) and once a month there after until the end of the experiment. Gas collection was executed between 11:00 am to 1:00 pm for each sampling event to avoid daytime interferences. Soil and air temperature, soil moisture content, and bulk density, were measured at corresponding soil respiration measurement times. In-field soil temperature and moisture were measured using a STEVENS Hydraprobe (Portland, Oregon), inserted $12.4 \mathrm{~cm}$ into the soil. Composite soil samples $(0-15 \mathrm{~cm}$ depth) were oven dried at $105^{\circ} \mathrm{C}$ for $24 \mathrm{~h}$ to obtain soil moisture content. Bulk density of soils was determined by cylinder method and ranged from 1.2 to $1.3 \mathrm{~g} \mathrm{~cm}^{-3}$. Rainfall and air temperature data was collected from the Florida Automated Weather Network (FAWN) meteorological station throughout the experiment. Bulk density was used to calculate water filled pore space (WFPS, \%) using the formula:

$$
\Psi=\left(\frac{\Phi \mathbf{v}}{\mathbf{T P}}\right) * 100
$$

where $\Psi$ is the volumetric water content (\%) and TP is the total porosity (\%) of the soil. The remaining collected soil samples were oven-dried $\left(30{ }^{\circ} \mathrm{C}\right.$ for $\left.48 \mathrm{~h}\right)$, sieved $(2 \mathrm{~mm})$, and ground for physicochemical analysis. Total carbon content was measured via dry combustion utilizing a Truspec Carbon/Nitrogen Analyzer (LECO Corporation, St. Joseph, MI). Measured C content of crop biomasses (harvested 90 days after germination, measured with and without manure applications) and dry biomass yields were used to calculate the amount of TC contributed by each cover crop followed the methods described by Wang et al. (2015).

\section{Soil C Balance Calculation}

Soil respiration $\left(\mathrm{CO}_{2}\right.$ emission from soil) is an active indicator of soil health and directly related to soil ecosystem productivity. Soil $\mathrm{C}$ balance (SCB) is the measurement of net $\mathrm{C}$ contributed by each cover crop and calculated as: 


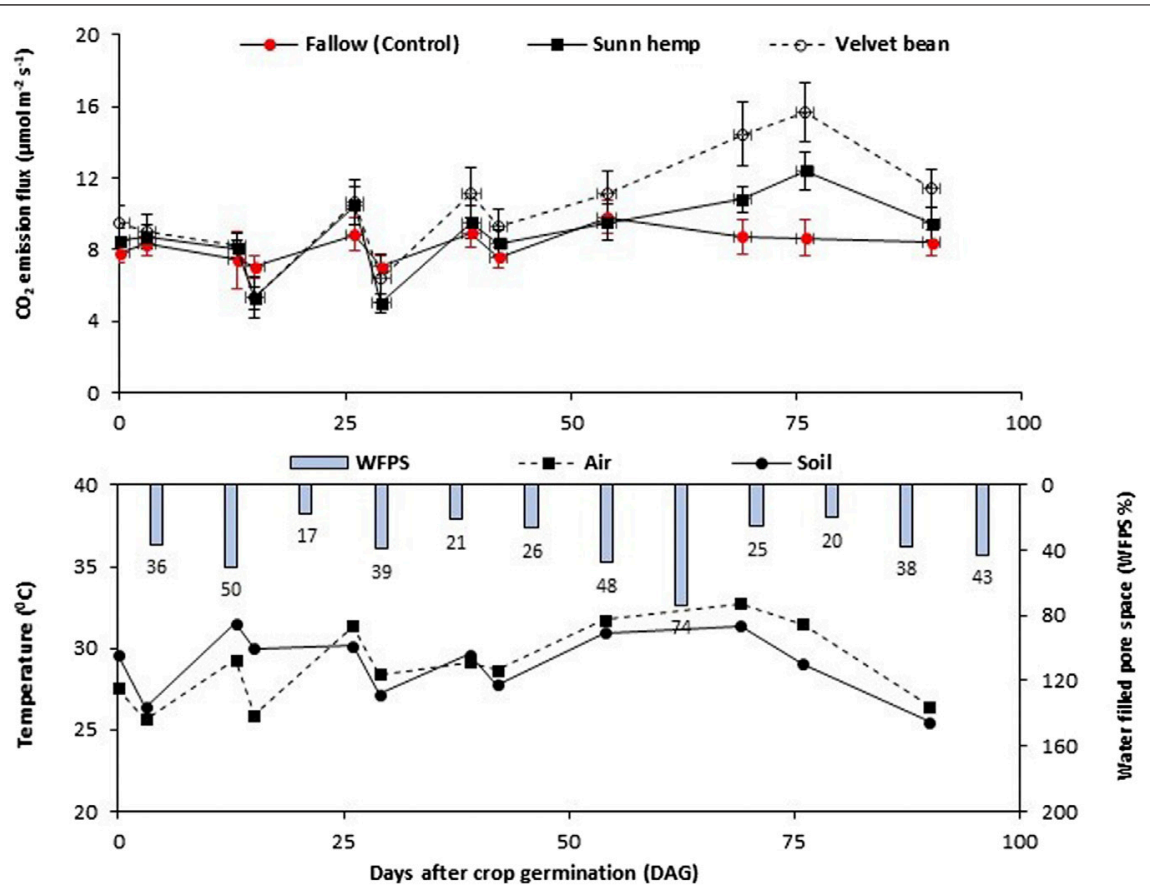

FIGURE 2 | Carbon dioxide $\left(\mathrm{CO}_{2}\right)$ emission fluxes from carambola orchard during cover crop (sunn hemp, SH and velvet bean, VB) growing season. Both cover crops were terminated 90 days after crop germination (DAG). Variances were homogeneous $(p<0.10)$; therefore, datasets were pooled and average values for two seasons are presented. Soil, air temperature $\left({ }^{\circ} \mathrm{C}\right)$ and water filled pore space (WFPS\%) data are also presented.

$$
\operatorname{SCB}\left(\mathrm{kg} \mathrm{ha}^{-1}\right)=(\text { TC contribution }- \text { TC removed })
$$

where TC is the total $\mathrm{C}$.

Soil C balances were developed for both cover crops (with and without manure application). Total $\mathrm{C}$ contribution was estimated based on the $\mathrm{C}$ content (\%) in the dry biomass of each CC and the amount of biomass produced by CCs in manure and without manure applied plots. The amount of TC removed was analyzed by calculating the total amount of $\mathrm{CO}_{2}$ produced in the soil (soil respiration) during CC growing seasons.

\section{Statistical Analyses}

Statistical analyses were conducted using SPSS (IBM Corp.). IBM SPSS Statistics for Windows (Version 25.0). Armonk, NY: IBM Corp.) and SAS (SAS Institute Inc. 1976. Base SAS ${ }^{\circledR}$ 9.4. Cary, NC: SAS Institute Inc.) software. A one-way analysis of variance (ANOVA) was performed to distinguish between the effect of treatment at each sampling time. A two-way repeated ANOVA with Tukey-Kramer post-hoc test was performed to analyze the treatment differences over time at $p<0.05$. We used a homogeneity of variance test to compare the variability of $\mathrm{CO}_{2}$ emission data between two seasons. As the variances were homogeneous $(p<0.10)$, we pooled the datasets and presented the average value for two seasons in this paper.

\section{RESULTS}

Emission of $\mathrm{CO}_{2}$ from experimental plots were separated for two timescales: A) $\mathrm{CO}_{2}$ emission from the day after crop germination till the day of CC termination (90 days) and B) $\mathrm{CO}_{2}$ emission from the day after CC termination (or the day manure was applied) to the end of this study (167 days). Average $\mathrm{CO}_{2}$ emission $\left(\mu \mathrm{mol} \mathrm{m} \mathrm{m}^{-2} \mathrm{~s}^{-1}\right.$ ) from the control plot (8.22) was similar to $\mathrm{SH}$ (8.85) throughout the CC growing seasons (Figure 2). However, $\mathrm{CO}_{2}$ emission from VB plots (10.21) was 23 and $15 \%$ higher than control and $\mathrm{SH}$ plots, respectively. The amount of $\mathrm{CO}_{2}-\mathrm{C}$ emission during the last few weeks (55-90 DAG) before CC termination was about $42 \%$ higher from both $\mathrm{SH}$ and VB plots than initial weeks of CC establishment. This is specifically because higher root respiration during full crop growth stages increased $\mathrm{CO}_{2}$ emission from the soil. Now while comparing the treatments after CC termination, we observed that $\mathrm{VB}$ with manure (VBM) plots produced the highest amount of $\mathrm{CO}_{2}-\mathrm{C}$ followed by $\mathrm{SHM}$ (Figure 3).

Carbon dioxide emission was observed immediately after manure application and high $\mathrm{CO}_{2}-\mathrm{C}$ emission peaks were observed (as high as $16 \mu \mathrm{mol} \mathrm{m} \mathrm{m}^{-2} \mathrm{~s}^{-1}$ ) within first couple of weeks after CC termination (or the manure was applied). In this study, $41 \%$ of the total $\mathrm{CO}_{2}$ emission was found within 20 days after crop termination (DAT). Overall, $\mathrm{CO}_{2}-\mathrm{C}$ emissions from manure applied plots (average $8,030 \mathrm{~kg} \mathrm{ha}^{-1}$ season $^{-1}$ ) were $17 \%$ higher than plots without manure treatment (average $6,870 \mathrm{~kg} \mathrm{ha}^{-1}$ season $^{-1}$ ) and the emission was significantly higher $(p<0.05)$ during 20 days after manure application.

Furthermore, we need to consider both positive and negative aspects of $\mathrm{CCs}$ in $\mathrm{CO}_{2}$ emission and total $\mathrm{C}$ contribution (from crop biomass analysis) during production. Positive $\mathrm{C}$ balances were found for both SH and VB (Table 2). An average $13200 \mathrm{~kg} \mathrm{ha}^{-1} \mathrm{TC}$ was contributed by $\mathrm{SH}, 33 \%$ higher TC than VB and comparing all plots, about $8-10 \%$ higher (not significant at $p<0.05$ ) TC 

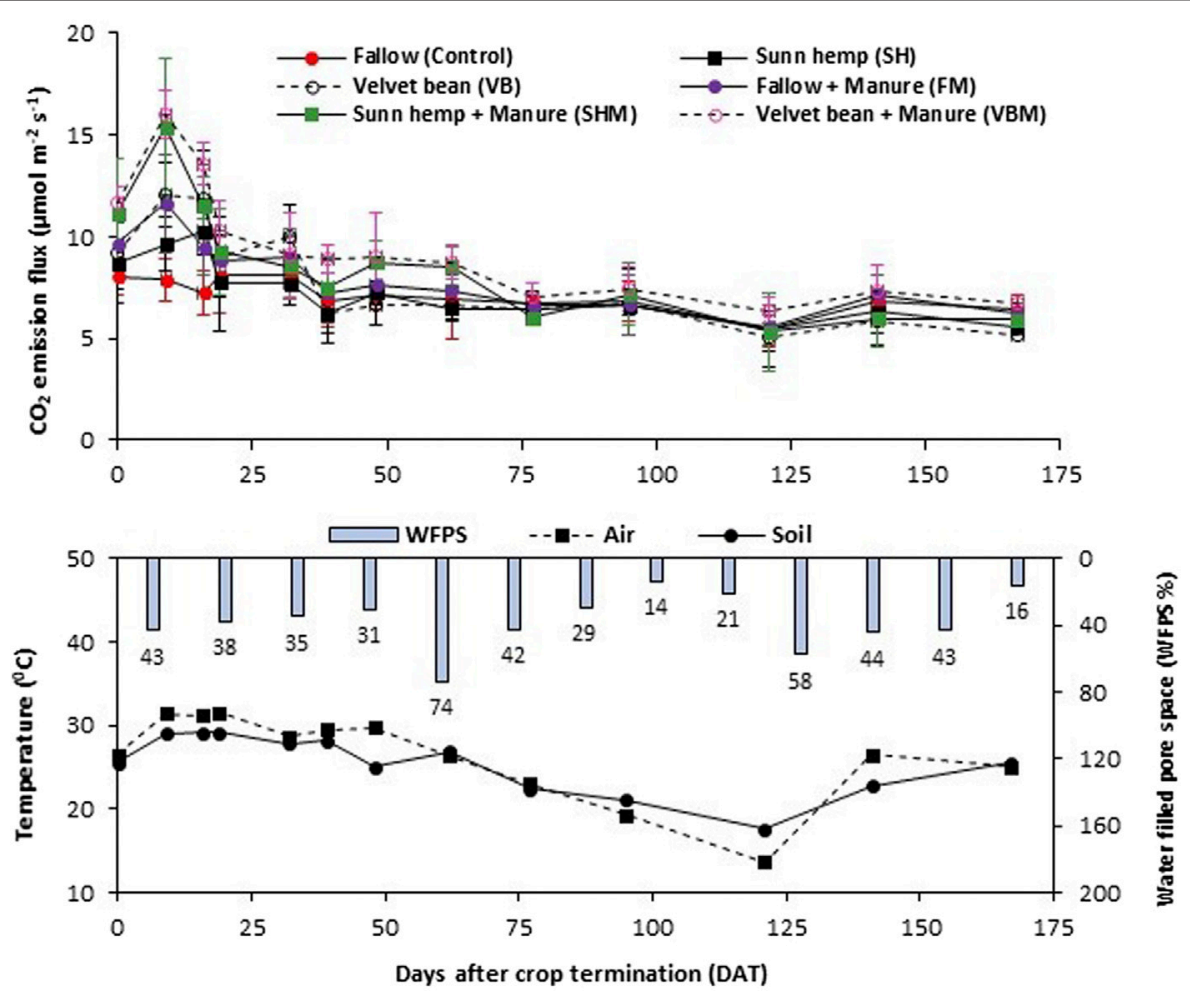

FIGURE 3 | Carbon dioxide $\left(\mathrm{CO}_{2}\right)$ emission fluxes from carambola orchard after cover crop (sunn hemp, SH and velvet bean, VB) termination. Manure was applied on the same day after cover crop termination (O DAT). Variances were homogeneous $(p<0.10)$; therefore, datasets were pooled and average values for two seasons are presented. Soil, air temperature $\left({ }^{\circ} \mathrm{C}\right)$ and water filled pore space (WFPS\%) data are also presented.

TABLE 2 | Carbon contribution, \% $\mathrm{C}$ in crop biomass, and $\mathrm{CO}_{2}$-C emissions from fallow (control) and cover crop (sunn hemp and velvet bean) treated plots in Carambola orchard for two growing seasons in South Florida, United States. Different letters indicate significant difference $(p<0.05)$ between treatments.

\section{Treatment}

Fallow (control)

Fallow + manure

Sunn hemp

Sunn hemp + manure

Velvet bean

Velvet bean + manure
Per season $\left(\mathrm{kg} \mathrm{ha}^{-1}\right)$

\begin{tabular}{ccc}
\hline $\mathbf{C O}_{\mathbf{2}}-\mathbf{C}$ emission $^{\mathbf{a}}$ & Total $\mathbf{C ~ c o n t r i b u t i o n ~}^{\mathbf{a}}$ & \% C in biomass \\
$6,627 \pm 679 \mathrm{~b}$ & $\mathrm{NA}^{*}$ & $\mathrm{NA}$ \\
$7,390 \pm 1,551 \mathrm{a}$ & $\mathrm{NA}$ & $\mathrm{NA}$ \\
$6,762 \pm 2,160 \mathrm{a}$ & $12,913 \pm 1,597 \mathrm{ab}$ & $48.6 \pm 4.9$ \\
$7,946 \pm 1,569 \mathrm{a}$ & $13,400 \pm 2,199 \mathrm{a}$ & $49.8 \pm 6.1$ \\
$7,234 \pm 1,645 \mathrm{a}$ & $9,512 \pm 1,168 \mathrm{c}$ & $46.9 \pm 5.7$ \\
$8,754 \pm 908 \mathrm{a}$ & $10,226 \pm 2085 \mathrm{bc}$ & $49.3 \pm 7.2$
\end{tabular}

a: Values indicate the average for two seasons.

*NA: not applicable.

contribution was observed from manure applied plots than plots where manure was not applied. The average fraction of emission vs $\mathrm{C}$ contribution $\left(\mathrm{CO}_{2}-\mathrm{C} / \mathrm{TC}\right)$ was 1.46 times higher in $\mathrm{VB}$ plots than $\mathrm{SH}$ plots. Higher $\mathrm{C}$ emission fraction from $\mathrm{VB}$ plots was also an indirect indication of lower $\mathrm{C}$ use efficiency by $\mathrm{VB}$ cropping system as compared to $\mathrm{SH}$.

\section{DISCUSSION}

Average annual rainfall was $13.25 \mathrm{~cm}$ in season one and 11.13 in season two, with relatively higher rainfall observed during July-
August (average of 18-24 cm per month) in both years as South Florida experiences a wet summer season and a dry winter season. Rainfall and water filled pore space (WFPS, \%; range: 17 to 74, average: 36) did not have any effect on $\mathrm{CO}_{2}$ emission from all plots, however, soil and air temperature had a significant effect $(p<0.10)$. For instance, higher $\mathrm{CO}_{2}$ emission peaks (at 13, 26, 39, 54 days after germination; DAG) were correlated to higher air and soil temperatures.

Higher soil and air temperature have been reported to increase root and microbial respiration (Huang et al., 2005). Similarly, increased $\mathrm{CO}_{2}$ emissions were observed with higher soil and air temperatures in previous studies conducted in the 
sub-tropical US (Wang et al., 2013; Dattamudi et al., 2019; Ray et al., 2020). Daily average $\mathrm{CO}_{2}-\mathrm{C}$ emission $\left(94 \mathrm{~kg} \mathrm{ha}^{-1}\right)$ during CC growing season from our experiment (Figure 2) corroborate well with other CC studies amended with organic manure (Ray et al., 2020). However, our study noted increased $\mathrm{CO}_{2}$ emission (3-4 times higher) when compared to other studies conducted in mineral soils in the same agroclimatic region (Tian et al., 2015; Dattamudi et al., 2019). This comparative analysis suggests that OM played a significant role (our soil had 17\% OM) in increasing soil microbial activity and root respiration during crop production. This can be compared to a recent study in which Bosco et al. (2019) reported that cumulative and daily $\mathrm{CO}_{2}$ emissions from organic systems were higher than an integrated cropping system for vegetable production. Additionally, lower $\mathrm{CO}_{2}$-C emissions were observed from fallow (control) plots than CC treatments. This result was likely caused by lower root respiration from those plots. Crop biomass production and ground cover of $\mathrm{SH}$ was higher than $\mathrm{VB}$, which resulted in lower soil temperature during $\mathrm{SH}$ production, and subsequently, a lower $\mathrm{CO}_{2}$ emission from soil during the $\mathrm{CC}$ growing season. Moreover, the quality and quantity of harvested CC biomass can also have an effect on soil respiration rates (Nilahyane et al., 2020), a possible factor impacting our results.

Furthermore, prior findings have supported that application of chemical fertilizers have little to no effect on $\mathrm{CO}_{2}$ emission from mineral soils (Dattamudi et al., 2019; Sistani et al., 2019). In our study, $\mathrm{CO}_{2}$-C emissions from manure applied plots was higher than those that were not treated with PM, specifically within the first 20 days of PM application. The spike in $\mathrm{CO}_{2}$ emission from manure applied plots possibly resulted from higher microbial degradation of $17 \%$ SOM along with increased root respiration in our soil. Average C:N ratio (mol:mol) of SH and VB leaf biomass were in the range of 12:1 to 17:1, similar to previous studies (Valenzuela and Smith, 2002). A C:N ratio lower than 15:1 indicates a net $\mathrm{N}$ mineralization in the soil (Hagemann et al., 2016) which likely resulted in higher microbial activity in manure and $\mathrm{CC}$ treated plots. Therefore, $\mathrm{CO}_{2}$ emission peaks were observed immediately after manure was applied (increased microbial activity and root respiration) in both crops. Large amounts of nutrients from CC biomass are often released 30-60 days after incorporation into the soil, which is highly dependent on the C:N ratio of the CC species (Lynch et al., 2016). As a result, a few $\mathrm{CO}_{2}$ emission peaks observed during 40-75 DAT were likely caused by an increased nutrient release in the second month after CC termination. Our findings indicate that soil respiration (and $\mathrm{CO}_{2}$ emission) can be influenced by the addition of macro and micronutrients if abundant food sources (SOM) are present for the microbial community. Interestingly, unlike the CC growing seasons, soil and air temperatures had very little effects on $\mathrm{CO}_{2}$ emissions after CC termination except for few relatively higher peaks (74 and 141 DAT) that corresponded to higher temperatures.
Higher TC contribution by SH (with and without manure) indicates that $\mathrm{SH}$ could be a stronger $\mathrm{CC}$ candidate for contributing $\mathrm{C}$ in organic rich soil than VB. In a study conducted in similar agroclimatic zone, Wang et al. (2012) found lower TC contribution by SH $\left(8.71 \mathrm{Mg} \mathrm{ha}^{-1}\right)$ and VB $\left(4.73 \mathrm{Mg} \mathrm{ha}^{-1}\right)$ monocultures in mineral soil, confirming that organic matter plays a major role in biomass production and subsequently TC contribution (our soil has $17 \%$ SOM) in soil. Soils in manure applied plots had higher TC regardless of the type of cover crop. It should be noted that average $\mathrm{C}$ content of the PM was $33.76 \pm 0.29 \%$, which would amount to $561 \pm 67$ $\mathrm{kg} \mathrm{ha}^{-1}$ of TC contribution, which could account for higher TC contribution in manure applied plots. Interestingly, total $\mathrm{C}$ contribution by $\mathrm{SH}$ was greater than $\mathrm{VB}$, but $\mathrm{CO}_{2}$ emission from VB was higher than $\mathrm{SH}$ plots. This indicates that $\mathrm{C}$ contributed by VB was likely in labile form which stimulated higher microbial activities and subsequently greater $\mathrm{CO}_{2}$ emissions. Another possible explanation could be the rate of crop biomass decomposition from $\mathrm{SH}$ and VB plots. Higher crop residue decomposition was reported to increase soil $\mathrm{CO}_{2}$ emission (Campos et al., 2011). We did not measure the biomass decomposition rate for $\mathrm{SH}$ and $\mathrm{VB}$, but in a recent study conducted in tropical area of Brazil, Xavier et al. (2017) categorized $\mathrm{SH}$ as a cover crop with great resistance to decomposition, while VB was categorized as intermediate resistance.

We understand that the soil $\mathrm{C}$ balance developed in this study was only from two crop growing seasons, and a long-term field experiment would be more suitable to determine the CC contribution of soil $\mathrm{C}$ dynamics. However, in comparing the short-duration effectiveness of $\mathrm{SH}$ and VB in contributing/ accumulating TC in the soil and influencing $\mathrm{CO}_{2}$ emission, our result suggest that $\mathrm{SH}$ has greater potential to reduce $\mathrm{CO}_{2}$ emissions from the soil. When sufficient $\mathrm{C}$ present in the soil, the addition of $\mathrm{N}$ and other nutrients combined with meteorological parameters can significantly influence soil respiration.

\section{DATA AVAILABILITY STATEMENT}

The original contributions presented in the study are included in the article/Supplementary Material, further inquiries can be directed to the corresponding author.

\section{AUTHOR CONTRIBUTIONS}

$\mathrm{AF}, \mathrm{YL}$, and $\mathrm{KJ}$ conceived and planned the experiment. AF carried out the experiment, processed the experimental data, and performed field/laboratory analysis. All authors contributed to the interpretation of the results. SD took the lead in writing the manuscript, statistical analysis, and creating figures. All authors provided critical feedback and input that helped shape the research, analysis, and manuscript. KJ supervised the work and provided funding for the project. 


\section{FUNDING}

Funding sources for this project: USDA-NIFA-NNF 2015-38420-23702, Florida International University Tropics and the Susan S. Levine Trust, and the Florida International University Graduate School Doctoral Evidence Acquisition and Dissertation Year Fellowships.

\section{REFERENCES}

Alluvione, F., Bertora, C., Zavattaro, L., and Grignani, C. (2010). Nitrous Oxide and Carbon Dioxide Emissions Following green Manure and Compost Fertilization in Corn. Soil Sci. Soc. Am. J. 74 (2), 384-395. doi:10.2136/sssaj2009.0092

Ballen, F. H., Evans, E., Crane, J., and Singh, A. (2020). Sample Profitability and Cost Estimates of Producing Sweet Flavored Carambola (Averrhoa Carambola) in South Florida. Edis 2020 (3), 7. doi:10.32473/edis-fe1079-2020

Bosco, S., Volpi, I., Antichi, D., Ragaglini, G., and Frasconi, C. (2019). Greenhouse Gas Emissions from Soil Cultivated with Vegetables in Crop Rotation under Integrated, Organic and Organic Conservation Management in a Mediterranean Environment. Agronomy 9 (8), 446. doi:10.3390/ agronomy 9080446

Campos, B.-H. C. d., Amado, T. J. C., Tornquist, C. G., Nicoloso, R. D. S., and Fiorin, J. E. (2011). Long-term C-CO2 Emissions and Carbon Crop Residue Mineralization in an Oxisol under Different Tillage and Crop Rotation Systems. Rev. Bras. Ciênc. Solo 35 (3), 819-832. doi:10.1590/s0100-06832011000300017

Canali, S., Trinchera, A., Intrigliolo, F., Pompili, L., Nisini, L., Mocali, S., et al. (2004). Effect of Long Term Addition of Composts and Poultry Manure on Soil Quality of Citrus Orchards in Southern Italy. Biol. Fertil. Soils 40, 206-210. doi:10.1007/s00374-004-0759-x

Crane, J. H. (2016). Carambola Growing in the Florida Home Landscape. UF/IFAS Extension.

Dattamudi, S., Wang, J. J., Dodla, S. K., Viator, H. P., DeLaune, R., Hiscox, A., et al. (2019). Greenhouse Gas Emissions as Influenced by Nitrogen Fertilization and Harvest Residue Management in Sugarcane Production. Agrosystems, Geosciences Environ. 2 (1), 1-10.

Gougoulias, C., Clark, J. M., and Shaw, L. J. (2014). The Role of Soil Microbes in the Global Carbon Cycle: Tracking the Below-Ground Microbial Processing of Plant-Derived Carbon for Manipulating Carbon Dynamics in Agricultural Systems. J. Sci. Food Agric. 94 (12), 2362-2371. doi:10.1002/jsfa.6577

Hagemann, N., Harter, J., and Behrens, S. (2016). "Elucidating the Impacts of Biochar Applications on Nitrogen Cycling Microbial Communities," in Biochar Application (Amsterdam: Elsevier), 163-198. doi:10.1016/b978-0-12-803433$0.00007-2$

Hobbs, P. R., Sayre, K., and Gupta, R. (2008). The Role of Conservation Agriculture in Sustainable Agriculture. Phil. Trans. R. Soc. B 363 (1491), 543-555. doi:10.1098/rstb.2007.2169

Huang, X., Lakso, A. N., and Eissenstat, D. M. (2005). Interactive Effects of Soil Temperature and Moisture on Concord Grape Root Respiration. J. Exp. Bot. 56 (420), 2651-2660. doi:10.1093/jxb/eri258

Jia, S., Liang, A., Zhang, S., Chen, X., McLaughlin, N. B., Sun, B., et al. (2021). Effect of Tillage System on Soil CO2 Flux, Soil Microbial Community and maize (Zea mays L.) Yield. Geoderma 384, 114813. doi:10.1016/ j.geoderma.2020.114813

Jones, J., Savin, M. C., Rom, C. R., and Gbur, E. (2020). Soil Microbial and Nutrient Responses over Seven Years of Organic Apple Orchard Maturation. Nutr. Cycl Agroecosyst 118 (1), 23-38. doi:10.1007/ s10705-020-10080-y

Kaiser, D. E., Mallarino, A. P., Haq, M. U., and Allen, B. L. (2009). Runoff Phosphorus Loss Immediately after Poultry Manure Application as Influenced by the Application Rate and Tillage. J. Environ. Qual. 38 (1), 299-308.

Lynch, M. J., Mulvaney, M. J., Hodges, S. C., Thompson, T. L., and Thomason, W. E. (2016). Decomposition, Nitrogen and Carbon Mineralization from Food and Cover Crop Residues in the central Plateau of Iofe. Springerplus 5 (1), 1-9. doi:10.2134/jeq2007.0628

\section{ACKNOWLEDGMENTS}

We would like to acknowledge Marc Ellenby and family for supplying LNB Groves as the field site for this experiment. We also thank Dr. Steven Oberbauer for technical instrumentation support and guidance.

Martínez-Mena, M., Perez, M., Almagro, M., Garcia-Franco, N., and Díaz-Pereira, E. (2021). Long-term Effects of Sustainable Management Practices on Soil Properties and Crop Yields in Rainfed Mediterranean almond Agroecosystems. Eur. J. Agron. 123, 126207. doi:10.1016/j.eja.2020.126207

Menocal, O., Kendra, P. E., Montgomery, W. S., Crane, J. H., and Carrillo, D. (2018). Vertical distribution and daily flight periodicity of ambrosia beetles (coleoptera: Curculionidae) in Florida avocado orchards affected by laurel wilt. Journal of Economic Entomology 111 (3), 1190-1196.

Muhammad, I., Sainju, U. M., Zhao, F., Khan, A., Ghimire, R., Fu, X., et al. (2019). Regulation of Soil CO2 and N2O Emissions by Cover Crops: A Meta-Analysis. Soil Tillage Res. 192, 103-112. doi:10.1016/j.still.2019.04.020

Nilahyane, A., Ghimire, R., Thapa, V. R., and Sainju, U. M. (2020). Cover Crop Effects on Soil Carbon Dioxide Emissions in a Semiarid Cropping System. Agrosystems, Geosciences Environ. 3 (1), e20012. doi:10.1002/ agg 2.20012

Nyakatawa, E. Z., Reddy, K. C., and Sistani, K. R. (2001). Tillage, Cover Cropping, and Poultry Litter Effects on Selected Soil Chemical Properties. Soil Tillage Res. 58 (1-2), 69-79.

Ray, R. L., Griffin, R. W., Fares, A., Elhassan, A., Awal, R., Woldesenbet, S., et al. (2020). Soil CO 2 Emission in Response to Organic Amendments, Temperature, and Rainfall. Scientific Rep. 10 (1), 1-14. doi:10.1016/s01671987(00)00183-5

Reddy, C. K., Nyakatawa, E. Z., and Reeves, D. W. (2004). Tillage and Poultry Litter Application Effects on Cotton Growth and Yield. Agron.j. 96 (6), 1641-1650. doi:10.2134/agronj2004.1641

Reddy, K. C., Malik, R. K., Reddy, S. S., and Nyakatawa, E. Z. (2007). Cotton Growth and Yield Response to Nitrogen Applied through Fresh and Composted Poultry Litter. J. Cotton Sci.

Rigon, J. P. G., Franzluebbers, A. J., and Calonego, J. C. (2020). Soil Aggregation and Potential Carbon and Nitrogen Mineralization with Cover Crops under Tropical No-Till. J. Soil Water Conservation 75 (5), 601-609.

Rosolem, C. A., Li, Y., and Garcia, R. A. (2016). Soil Carbon as Affected by Cover Crops under No-Till under Tropical Climate. Soil Use Manage 32 (4), 495-503. doi:10.1111/sum.12309

Sanz-Cobena, A., García-Marco, S., Quemada, M., Gabriel, J. L., Almendros, P., and Vallejo, A. (2014). Do cover Crops Enhance N2O, CO2 or CH4 Emissions from Soil in Mediterranean Arable Systems? Sci. Total Environ. 466-467, 164-174. doi:10.1016/j.scitotenv.2013.07.023

Schlesinger, W. H., and Andrews, J. A. (2000). Soil Respiration and the Global Carbon Cycle. Biogeochemistry 48 (1), 7-20. doi:10.1023/a: 1006247623877

Scholberg, J. M. S., Dogliotti, S., Leoni, C., Cherr, C. M., Zotarelli, L., and Rossing, W. A. H. (2010). Cover Crops for Sustainable Agrosystems in the Ioferti. Genetic Engineering, Iofertilization, Soil Quality and Organic Farming. Berlin: Springer, 23-58. doi:10.1007/978-90-481-8741-6_2

Sistani, K. R., Simmons, J. R., Jn-Baptiste, M., and Novak, J. M. (2019). Poultry Litter, Biochar, and Fertilizer Effect on Corn Yield, Nutrient Uptake, N2O and $\mathrm{CO} 2$ Emissions. Environments 6 (5), 55. doi:10.3390/ environments6050055

Tian, Z., Wang, J. J., Liu, S., Zhang, Z., Dodla, S. K., and Myers, G. (2015). Application Effects of Coated Urea and Urease and Nitrification Inhibitors on Ammonia and Greenhouse Gas Emissions from a Subtropical Cotton Field of the Mississippi delta Region. Sci. Total Environ. 533, 329-338. doi:10.1016/ j.scitotenv.2015.06.147

USDA National Cooperative Soil Survey (1991). National Resource Conservation Service. U.S. Department of Agriculture. Available at: https://soilseries.sc.egov. usda.gov/OSD_Docs/K/KROME.html.

Valenzuela, H., and Smith, J. (2002). Tropic Sun' Sunnhemp, (Green Manure Crops). 
Wang, J. J., Dodla, S. K., Viator, S., Kongchum, M., Harrison, S., Mudi, S. D., et al. (2013). Agricultural Field Management Practices and Greenhouse Gas Emissions from Louisiana Soils. La. Agric. 56 (2), 8-9.

Wang, Q., Li, Y., and Alva, A. (2012). Cover Crops in Mono- and Biculture for Accumulation of Biomass and Soil Organic Carbon. J. Sustain. Agric. 36 (4), 423-439. doi:10.1080/10440046.2011.627991

Wang, Q., Li, Y., Hanlon, E. A., Klassen, W., Olczyk, T., and Ezenwa, I. V. (2015). Cover Crop Benefits for South Florida Commercial Vegetable Producers, Gainesville, Florida, United States: University of Florida Institute for Food and Agricultural Sciences Extension. Document SL 242.

Xavier, F. A. d. S., Oliveira, J. I. A., and Silva, M. R. d. (2017). Decomposition and Nutrient Release Dynamics of Shoot Phytomass of Cover Crops in the Recôncavo Baiano. Revista Brasileira De Ciência do Solo, 41, e0160103. doi:10.1590/18069657rbcs20160103

Zhang, Z., and Peng, X. (2021). Bio-tillage: A New Perspective for Sustainable Agriculture. Soil Tillage Res. 206, 104844. doi:10.1016/j.still.2020.104844
Conflict of Interest: The authors declare that the research was conducted in the absence of any commercial or financial relationships that could be construed as a potential conflict of interest.

Publisher's Note: All claims expressed in this article are solely those of the authors and do not necessarily represent those of their affiliated organizations, or those of the publisher, the editors and the reviewers. Any product that may be evaluated in this article, or claim that may be made by its manufacturer, is not guaranteed or endorsed by the publisher.

Copyright (c) 2021 Freidenreich, Dattamudi, Li and Jayachandran. This is an openaccess article distributed under the terms of the Creative Commons Attribution License (CC BY). The use, distribution or reproduction in other forums is permitted, provided the original author(s) and the copyright owner(s) are credited and that the original publication in this journal is cited, in accordance with accepted academic practice. No use, distribution or reproduction is permitted which does not comply with these terms. 